\title{
28. Seventeen Days to Power: Making a minority government
}

\author{
Brian Costar ${ }^{1}$
}

The 2010 federal election produced two major surprises. A first-term government whose electoral position had seemed unassailable as recently as six months earlier was almost defeated; had it been, it would have been the first to suffer that fate since the Great Depression election of 1931. And Australia witnessed the first 'hung' parliament - an 'unavoidable idiom' (Justice Committee 2010, $2 ; 7)$ - and subsequent minority government since the one that emerged from the 1940 election when the nation was at war. The first of these surprises is the subject of detailed analyses in the earlier chapters of this volume. This chapter's purpose is to examine the dynamics of the 17 days from 21 August to 7 September, which produced a minority Labor administration supported by three Independents and one Greens MP. Tempting as it is to provide a dayby-day account, this chapter emphasises the major issues and developments during those days against the background of political and personal ambition and established constitutional principles - with many of the latter appearing novel to some of the contestants and commentators.

\section{Responses}

As soon as it became clear that neither the Australian Labor Party nor the Liberal-National party Coalition was likely to obtain a clear majority (76 of 150 members) in the House of Representatives, observers were quick to prognosticate as to the implications for the future and especially the economic future. There were pessimists, generally in the business sector and the media, and optimists, generally among political scientists. Some predicted 'an unprecedented period of political uncertainty' (Marks 2010) blighted 'by minority rule without any clear policy mandate' (Stuchbury 2010) because the 'stability of the de facto two-party system has... been shaken' (Ashdown 2010). Many business leaders and financial journalists were concerned about the lack of economic certainty that could 'stifle' Australia's economic reforms (Asiamoney.com 2010) because 'business owners and investors in business love certainty' and regard 'policy negotiation' as 'romantic' and 'decidedly unstable and short-term' (Bouris 2010). Not all of business was so despondent: Shane Oliver, chief economist at

1 I would like to thank Peter Browne of the Institute for Social Research at Swinburne University for his assistance in the preparation of this chapter. 
AMP Capital, drew attention to the fact that the Senate was frequently 'hung', which meant that 'having to negotiate policy through parliament has always been a fact of life in Australia' (Asiamoney.com 2010).

In fact, some of the more senior business-oriented economists were in the optimist (or, at least, realist) camp. Ed Shann, a former Treasury official and now an independent economist, expected that the hung Parliament would actually improve public policy debate 'because the minority government would be forced to provide better information to the Parliament and the public'. He was not fazed by the possibility of 'ineffective' government because Australia's economic growth was driven by external factors and the independent Reserve Bank would control monetary policy and inflation (Shann 2010). Saul Eslake, the former chief economist at ANZ Bank now working for the Grattan Institute, agreed and predicted accurately that the financial markets would not be panicked by the inconclusive election result because they had experience of minority governments in Europe and elsewhere-including the Australian States. He argued that those experiences 'don't justify the conclusion that hung parliaments necessarily result in bad or ineffectual governments, at least from a business or financial markets perspective' (Eslake 2010).

Others had more specific hopes, with Frank Zumbo, a consumer-law academic, welcoming a minority government of either persuasion because it would 'dampen the power of the faceless power-brokers' and open up the policy debate 'about the poor state of our competition laws' (Zumbo 2010). A more sectional angle was represented by a journalist at the rural Weekly Times, who looked forward to a 'bonanza' for the 'bush' because of the likelihood of three regional Independents being 'kingmakers' in the new Parliament (White 2010).

The political-science optimists generally were more concerned with accountability and the capacity of a hung parliament to restrain the executive arm of government. John Uhr of The Australian National University represented the consensus by making the early prediction of a transformation in politics for at least the next three years because the big parties would have to negotiate with Independents in the lower house and, after 1 July 2011, with the Australian Greens in the Senate. While he thought it unlikely that a hung parliament would occur twice in a row, open government, and parliamentary and electoral law reforms enacted during the next three years 'might prove difficult to reverse even under a majority government' (Mannheim 2010).

It is not surprising that the first federal hung parliament in 70 years was regarded as a novelty given that, other than in the Senate, Australia's twoparty-dominant configuration has proved remarkably resistant to the political fragmentation common in comparable Western democracies. At the last federal election to produce a hung parliament, in 1940, the Coalition and Labor each 
won 36 seats and two Independents held the balance of power. ${ }^{2}$ The two initially supported Prime Minister Robert Menzies, but in 1941 - by which time Menzies (like Kevin Rudd in 2010) had been removed by his party - they switched their support to Labor and John Curtin became Prime Minister. Political historian Rodney Cavalier has fairly judged that the hung Parliament of 1940-43 'served Australia well' (Cavalier 2010), but the passage of time and the vastly different circumstances of a world war reduce its comparative relevance to the twentyfirst century.

Of course, Australia has had much more recent experience of hung parliaments and minority governments. At various times since 1989, all the States and Territories have been governed by minority administrations, some of them more than once and some for a considerable period (Griffith 2010, 11-37). The last was formed as recently as March 2010 in Tasmania when, following the State election, a minority Labor government was sustained in office by the Greens, one of whom joined the cabinet and another of whom was appointed a parliamentary secretary. Nevertheless, as numerous as these recent examples are, they have occurred only in the sub-national jurisdictions in a federation in which the central government is far more powerful and important.

\section{The Crossbenchers}

Australians expect to know the result of federal elections within hours of the close of voting. But this was the first genuinely close election since 1961, and its impact on the final composition of the House of Representatives was not settled until more than a week later. Yet it was clear from election night that neither Labor nor the Coalition would harvest the 76 seats necessary to form a majority administration. This immediately brought into play the crossbench MPs, some of whose votes would be required to create and sustain a government. Who were they? The three sitting Independents, each of whom was comfortably returned, were Bob Katter, in the Queensland division of Kennedy, and NSW Independents Tony Windsor, in New England, and Rob Oakeshott in Lyne. On election night they were joined by two new members not formally aligned with Labor or the Coalition: Adam Bandt, who won the division of Melbourne for the Australian Greens, and Tony Crook of the WA Nationals, who defeated long-term Liberal MP Wilson Tuckey in the division of $\mathrm{O}^{\prime}$ Connor. ${ }^{3}$ Four days

2 In fact, it was slightly more complex than that, with the Coalition actually winning 37 seats but including the highly 'independent' Country Party Member for Wimmera, Alex Wilson; the Victorian Country Party was then deeply divided over its support for the federal Coalition. The one Independent was Arthur Coles who, despite being a member of the United Australia Party, won the Victorian division of Henty as a 'non-party' candidate (Martin 1993:302 ff.).

3 Tony Crook described himself as a member of 'The Nationals Western Australia' rather than as a member of the federal Coalition. He was reluctant to attend Coalition party meetings and decided to sit on the 
after polling day, these five were joined by Independent Andrew Wilkie, who wrested the Tasmanian division of Denison from Labor despite securing only 21 per cent of the primary vote.

Given that the crossbench MPs, the Prime Minister, the Leader of the Opposition and their senior colleagues and advisers would all be involved in negotiations to produce a government, the personalities and political backgrounds of the players were of significance. Katter, Windsor and Oakeshott all represented regional constituencies (commonly referred to as 'rural') and were experienced politicians at either federal or State level. All three had previously been associated with The Nationals but had departed it in acrimony; in Windsor's case the breach ran so deep that he responded to election-night criticism from The Nationals Senator Barnaby Joyce by describing him as 'a fool' (Murphy and Arup 2010). Windsor had been in a similar position once before, as one of three Independents who had supported the Greiner Coalition Government in New South Wales when it almost lost office at the 1991 election; later that year, he was a signatory to an agreement with the government that ushered in a series of parliamentary reforms. ${ }^{4}$ Andrew Wilkie had an entirely different background: once a member of the Liberal Party, he joined the Greens and ran unsuccessfully against John Howard in Bennelong in 2004. A former army officer, he had resigned as an intelligence analyst with the Office of National Assessments in 2003 'in protest at the Howard government's deceitful justification for joining in the invasion [of Iraq]' (Wilkie 2010, ix). Bandt, an industrial lawyer, had been a branch member of the Labor Party but contested the seat of Melbourne for the Greens in 2007 before winning it in 2010. Crook was a product of the often rancorous relations between the Liberal and Nationals parties in Western Australia and his attitude to supporting the federal Coalition was unpredictable. In short, despite commentary linking four of the six to the conservative side of politics, none of them had a strong emotional attachment to the non-Labor parties.

\section{Negotiating Government}

On Wednesday, 25 August, the Independents gathered in Canberra to begin discussions with the major parties and each other. After meeting Julia Gillard and Tony Abbott, they were joined by Adam Bandt before a large audience at the

crossbenches, but his uncertain affiliation meant he played little part in the negotiations over government formation.

4 Among the reforms were a referendum on four-year parliamentary terms (which was held and passed), a referendum on the independence of the judiciary (also passed) and the introduction of parliamentary estimates committees and whistleblower protection for public servants. According to Rodney Smith (2006:157), 'most of the reforms were achieved in some part, easily making the "fabulous fiftieth parliament" the period in which independents played the greatest legislative role since $1910^{\prime}$. 
National Press Club. Their presentation was a relatively light-hearted affair with little policy or other detail revealed, though the bonhomie on display suggested that the four could operate as a bloc — or, as they described themselves, 'the gang of four' (Murphy and Arup 2010). As to be expected, the crossbenchers were on the receiving end of an avalanche of 'advice' - some public and some private. The News Limited Press, supported by conservative radio commentators, strongly pushed them in the direction of a Coalition minority government (ABC 2010c) because they represented 'conservative' electorates. On 4 September, The Australian continued its campaign with the publication of Newspoll findings that suggested voters in the three Independents' seats wanted them to support the Coalition.

A range of commentators and political figures argued that the Independents had a 'moral' duty to support whichever party won a 'majority' (ABC 2010a). This contention - of dubious constitutional provenance-became a moving narrative, with seats, first-preference and two-party preferred votes used interchangeably as the decisive factor (Brent 2010). Privately, they were bombarded with phone, email, text and tweet messages. Senator Bill Heffernan created controversy when he phoned Rob Oakeshott's home and introduced himself as 'the devil' - apparently a habitual greeting for this high-profile parliamentarian. Unfortunately, Oakeshott's wife, who took the call, 'thought it was a kook and hung up'. Heffernan later tried to apologise (Coorey 2010a).

The pressure on the three regional Independents - much of it partisan, ahistorical or misinformed - continued until day seventeen. Commentator Tony Smith was scathing in his assessment of the role of the media: 'the independents have been treated contemptuously...as opportunists, impractical idealists and vengeful egotists', which he explained was the result of too many journalists' inability to transcend the 'in-out' nature of the Westminster system (Smith 2010, 5).

\section{Enter the Governor-General}

Because of majority results in the 27 successive federal elections held since 1940, the role of the Governor-General in choosing a prime minister has been constitutionally anodyne. As constitutional expert Anne Twomey has correctly observed: 'While the role and powers of the Governor-General in relation to the formation of government in a hung Parliament are uncertain to the extent that they are not codified, they are strictly confined by convention' (Twomey 2010, 25). Yet memories of Remembrance Day 1975 - when the Governor-General dismissed a government because of its failure to secure the passage of supply 
through the Senate - remain strong within the political class, and the novel 2010 result raised questions about the role of the Governor-General in the event of a prolonged political impasse.

Few, however, expected that the family circumstances of the current incumbent, Quentin Bryce, would emerge as a mooted impediment to her exercising her constitutional functions. But on 23 August it was reported that, among others, 'a leading Australian ethicist', Dr Leslie Cannold (Tedmanson 2010), was arguing that Ms Bryce should play no part in the process of forming a new government because her daughter was married to Bill Shorten MP, a parliamentary secretary in the Gillard Government. 'It is important for the Governor General to recognise there is at least the appearance of a conflict and that she should excuse herself from deciding who forms the next government' (Cannold 2010; Tabakoff 2010).

Untroubled by the principle of the separation of powers, a prominent barrister, Peter Faris QC, suggested that the Chief Justice of the High Court could deputise for the Governor-General (Gibson and Welch 2010). The Chief Justice himself, Robert French, did not directly respond to Faris, but made it clear that, unlike in 1975, neither he nor the other High Court justices would be tendering advice to the Governor-General (Gordon et al 2010). Constitutional precedent, practice and convention provided little support to the Cannold/Faris contentions, but the Governor-General prudently sought the formal advice of the Solicitor-General as to whether her family circumstances created 'any constitutional or other legal impediment to the proper exercise of my functions' (Bryce 2010). His response was clear and unequivocal:

The functions of the Governor-General are of the highest constitutional order. The circumstances in which the Governor-General might conceivably come to perform those functions in the exercise of the Governor-General's own deliberative judgment are, by definition, extraordinary...Yet the maintenance of the capacity of the GovernorGeneral to act in such circumstances is critical. The notion that the Governor-General might in such circumstances be constitutionally inhibited in the performance of her functions by reason of a perception of bias or of a conflict of interest is one that, in my opinion, finds no foothold in the structure or text of the constitution. (Gageler 2010a, 2)

Consequently, he advised that the 'marriage of her daughter to Mr Shorten gives rise to no constitutional or other legal impediment to the proper discharge of her functions of office' (Gageler 2010a, 4). 


\section{The Negotiations Continue...}

Meanwhile, the negotiations among the big parties and the crossbench MPs were proceeding in the expectation that they would involve a series of 'agreements' covering areas of parliamentary and electoral reform as well as policy commitments. The first of these-between Labor and the Greens - was somewhat peripheral to the actual task of forming government but did formalise Adam Bandt's commitment to Labor (Greens 2010). Its significance lay in the fact that from 1 July 2011 the Labor and Greens senators would constitute a majority in the upper house and have the capacity to influence (positively or negatively) the legislative agenda of a government of either party. The agreement contained a series of policy objectives, especially in the area of the environment, and proposed parliamentary and electoral reforms.

It was overshadowed, however, by the release, later on the same day (1 September), of the Treasury's economic analysis of the Coalition's election policies. Tony Abbott had initially resisted any such costing on the grounds that it could be subject to political interference by ministers, but relented when the Independents became insistent. The Coalition's economic creditability took a blow when Treasury identified a $\$ 3.5$ billion shortfall in its costings. The next day, Andrew Wilkie controversially rejected a $\$ 1$ billion offer from Tony Abbott to rebuild a hospital in his home State of Tasmania, describing it as 'reckless'. He also announced that he had entered a formal agreement to support Labor in supply and confidence votes (ABC 2010b). Labor could now count on 74 House of Representatives votes to the Coalition's 73, which meant that the decisions of Katter, Windsor and Oakeshott would determine who became prime minister.

\section{The Decision}

Needless to say, many of the exchanges among the three Independents, the parties and their advisers were and remain confidential. But a valuable snapshot into the deliberations of Katter, Windsor and Oakeshott was provided by ABC TV's Four Corners program, which was permitted to film some of their meetings. The program ('The deal': ABC 2010c), which aired on 4 October 2010, revealed the friendship and respect that had developed between the three and also the pressure they were under to come to a decision. Each was insistent that the needs of regional and rural Australia were paramount, but it remained uncertain whether they could maintain unity. The parliamentary arithmetic meant that Tony Abbott needed the votes of all three to become prime minister whereas Julia Gillard needed only two. 
Katter was the first to announce his intention. While Katter's choice seemed to have been reached at the eleventh hour, there had been earlier indications of his final direction. During the negotiations Katter had described himself 'as the anti-Greens Member of Parliament' and was very uncomfortable with the agreement struck between the Greens and Labor on 1 September (ABC 2010c, 5). Significantly, he did not attend the briefings on climate change given to the other Independents by Lord Nicholas Stern and Professor Ross Garnaut. It was also reported that he had assembled a new team of advisers during the interregnum, some with Liberal Party connections, who convinced him to moderate his criticisms of the Coalition. Finally, he produced a 20-point negotiation list, which he put to Julia Gillard and Tony Abbott on 2 September on the basis that his support would go to whoever endorsed the bulk of it. Given that the document demanded there be no carbon or mining tax and no emissions trading scheme, it was not surprising that Labor rejected it. In fact, some accused Katter of structuring the document to achieve that very outcome (ABC 2010c, 10).

Katter's two Independent colleagues also made it clear to him that 'we're not going to make a decision based on your judgment of your 20-point plan' (ABC 2010c, 11). In a delayed, dramatic and lengthy media conference on the afternoon of 7 September, both declared that they would support a minority Labor administration on supply and confidence votes and treat ordinary legislation on its merits, thus ensuring that Julia Gillard would continue in the office of prime minister.

Given that it was the decision by Windsor and Oakeshott that ultimately determined who took government, it is important to examine their motives. They claimed that the three major policy issues that influenced them were regional education, the National Broadband Network (NBN) and climate change, and that in each case Labor's position was closer to their views than the Coalition's (ABC 2010c, 11). Policy was doubtless important, but so were political imperatives. As early as one day after the election, Rob Oakeshott publicly commented that the Independents 'would have to take into account the make-up of the Senate' (AAP 2010). Had the Independents installed a minority Coalition government it would have faced a Labor-Greens majority after 1 July 2011, which might well have curtailed or amended its legislation-including items negotiated with the Independents. Of greater significance was the strong desire of the Independents to avoid an early election and the likelihood of a return to majority government. Not only might this endanger the various policy and parliamentary reform agreements the Independents had negotiated with the big parties, but also their 'balance of power' influence would evaporate. Given the relative performances 
of the big parties at the 2010 poll, the Independents reckoned that a Coalition minority government would be more inclined to call an early election than a Labor one.

Tony Windsor and Rob Oakeshott then signed formal agreements with the Prime Minister and her deputy, Wayne Swan. These comprised four parts: a covering letter detailing proposed initiatives in each one's electorate; the 'agreement' proper, which related to supply and confidence and access of the Independents to the Prime Minister and other ministers; Annex A, which contained detail of proposed reforms to parliamentary and governmental procedures; and Annex B, which committed the government to a broad range of regional policy initiatives. The covering letters contained some remarkably local and specific commitments; Oakeshott, for example, was promised the 'upgrade of the Bucketts Way at Krambach - the main regional road between Gloucester and Taree' (Gillard 2010). The agreement signed, the second Gillard Government was sworn into office by the Governor-General on 14 September 2010.

\section{Parliament and Pairs}

It would be wrong, however, to suggest that the issue of parliamentary reform was altogether drowned in a sea of last-minute pork-barrelling. Annex A of the Prime Minister's agreement with the Independents, which dealt with parliamentary reform, had been negotiated by Rob Oakeshott and agreed to by both Labor and the Coalition earlier in the 17-day period. While it contained many important changes to the working of the House of Representatives, it was not particularly far-reaching and largely mirrored procedures that had operated in the Senate for many years. One of the perennial issues it addressed was the question of how to increase the 'independence' from party influence of the Speaker of the House. One clause required that 'both the Speaker and Deputy Speaker will, when in the Chair, be paired' (Gillard 2010, Annex A, 2.1). Even before the new Parliament sat, a controversy arose as to whether such an unusual arrangement was constitutionally permissible. In a parliament in which the majority is wafer thin, the granting of permanent pairs can provide the government with an additional buffer against defeat. Soon after the government was sworn in, Opposition Leader, Tony Abbott, began to express concerns over his earlier offer to pair the Speaker - especially as rumours persisted that Rob Oakeshott might take up the post (Massola 2010).

The pertinent section of the Constitution was Section 40, which states: 'Questions arising in the House of Representatives shall be determined by a majority of votes other than that of the Speaker. The Speaker shall not vote unless the numbers are equal, and then he shall have a casting vote.' 
Pettifer's House of Representatives Practice explains that

the pairs system...is an unofficial [his emphasis] arrangement...which enables a Member from one side of the House to be absent for any votes when a Member from the other side is to be absent at the same time or when...a member abstains from voting. By this arrangement...the relative voting strengths are maintained. (Harris 2005, 278)

Hitherto, the Australian Parliament had no experience of the granting of pairs to presiding officers. To clarify the matter, the government asked the SolicitorGeneral to provide advice on whether there was a constitutional impediment to a pairing arrangement involving the Speaker. The short answer was 'no', but the provisos and qualifications contained in the detail of his advice effectively nullified any numerical advantage the government might have been seeking. He advised that no arrangement could confer on the Speaker a deliberative vote, nor could it deprive him of a casting vote. He also agreed that the entire arrangement 'could only be voluntary' - meaning, of course, that it could be vetoed by the Opposition (Gageler 2010b).

Shadow Attorney-General, Senator George Brandis, went further and advised Tony Abbott that 'to extend pairing arrangements to the speaker would, in effect, be to treat the speaker's vote, proleptically, as if it were a deliberative vote, which is a plain violation of the prohibition section 40' (Brandis quoted in Drape 2010). Whether for constitutional or political reasons, the Opposition confirmed it would not grant a pair to the Speaker. When the Parliament met on 28 September, Labor's Harry Jenkins was elected to serve a second term, the only minor controversy being that Labor and some of the crossbenchers elected Liberal MP Peter Slipper as his deputy over the Opposition's official nominee, Bruce Scott, who was chosen as Second Deputy Speaker (Australian Parliamentary Debates 2010, 29).

\section{Minority Government and the Future}

The first session of the 43rd Parliament met on 28 September and rose for the Christmas recess on 25 November. Given the dramas of the election and the post-election period, it was a relatively mundane affair. Fifty-six bills passed the House of Representatives and the government lost only three divisions - none of them on legislation. An early indication that there had occurred at least some changes to the rules of the parliamentary game was the passage of the Evidence Amendment (Journalists' Privilege) Bill 2010, which strengthened the law permitting journalists to protect the identity of their source. Its significance lay in the fact that it was sponsored by Independent MP Andrew Wilkie and became the first Private Member's Bill to pass the House since 1996. The voting patterns 
of the six crossbenchers were unremarkable, save for one exception. Windsor, Oakeshott, Wilkie and Bandt were government loyalists whereas Crook gave 28 votes to the Coalition and only eight to the government. The surprise was Bob Katter who, despite his endorsement of a minority Coalition administration, voted with Labor in 22 of 33 divisions (Horne 2010, 7). Veteran press gallery correspondent Laura Tingle was positive in her end-of-year assessment of the performance of the new-look Parliament:

Despite all the dire predictions [and]...despite the disappointment of newspaper editors determined to see it as an unmitigated disaster, the end-of-term report on how the hung parliament has been working must be that it has been operating effectively, whether at the level of a clearing house of ideas or as a legislative workhorse. (Tingle 2010)

Sceptics might respond that these are very early days and that the government's 'majority' is so precarious that its collapse and a consequential early election are inevitable. History does not support such a prediction: the 1940-43 hung Parliament ran its term despite experiencing a change of government, and so have the post-1989 State and Territory minority Parliaments. It is true that the loss by Labor of just one of its seats to a Coalition candidate in a by-election ${ }^{5}$ would imperil its position, but even then an election would not be likely. Assuming big-party loyalty and a split of the crossbenchers four to two for Labor, the government would be left with 74 deliberative votes (exclusive of the Speaker) to the Coalition's 75, paving the way for the moving of a constructive vote of no-confidence. If such a vote were carried, convention and precedent would require Julia Gillard to resign as prime minister and advise the GovernorGeneral to commission Tony Abbott. In the unlikely event that Gillard advised a dissolution of the House, it would quite properly be refused.

The only politically plausible path to an early election would be if Prime Minister Gillard, with her House 'majority' intact and emboldened by positive opinion polls, advised a dissolution to attempt to gain a party majority. As well as being a breach of an agreement with Tony Windsor and Rob Oakeshott that the next election will be held in September or October 2013, any election held before August of that year would be for the House of Representatives only, with a separate half-Senate election required to be held later for those senators set to retire in mid-2014. Even if the preconditions for a double-dissolution election were in place, Section 57 of the Constitution dictates that it could not be held

5 While there have been 37 by-elections for the House of Representatives since 1980, only three have been occasioned by death (one a suicide). It is an actuarial fact that members in the twenty-first century are much younger, fitter and healthier than those in earlier parliaments. 
after April 2013. It is possible that Australia will have a different government before the end of 2013, but it is improbable that an election will occur before then.

\section{References}

Australian Associated Press (AAP). 2010. 'Independents to back "stable government"'. Australian Associated Press, 22 August.

Australian Broadcasting Corporation (ABC). 2010a. 'Labor back in front as election lead see-saws'. ABC News, 31 August, <http:/www.abc.net.au/ news/stories/2010/08/31/2998169.htm>

Australian Broadcasting Corporation (ABC). 2010b. 'Wilkie announces support for Labor'. 7.30 Report, 2 September, ABC TV, <www.abc.net.au/7.30/ content/2010/s30001110.htm>

Australian Broadcasting Corporation (ABC). 2010c. 'The deal'. [Program transcript]. Four Corners, 4 October, <www.abc.net.au/4corners/ content/2010/s3029262.htm>

Australian Parliamentary Debates. 2010. House of Representatives, 28 September, Australian Parliamentary Debates.

Ashdown, Neil. 2010. 'Election 2010: independents hold balance of power in Australian coalition negotiations'. Global Insight, 26 August.

Asiamoney.com. 2010. 'Australia's politics takes on a Green hue'. Asiamoney.com, 1 September.

Bouris, Mark. 2010. 'Hazards lurk in minority rule'. The Sunday Telegraph, 29 August.

Brent, Peter. 2010. 'Who won the national vote?'. The Australian Online, 24 August, <http://blogs.theaustralian.news.com.au/mumble/index.php/ theaustralian/comments/who_won_the_national_vote/>

Bryce, Quentin. 2010. Letter to Gageler, S., Solicitor-General, 23 August, Government House, Canberra.

Cannold, Leslie. 2010. 'How some manipulators have hijacked GG's moves'. The Sun-Herald, 29 August.

Cavalier, Rodney. 2010. 'Hung parliament in wartime was one of our best'. The Australian, 2 September. 
Coorey, Phillip. 2010a. 'Liberal identified as making "Rambo-style" devil call'. Sydney Morning Herald, 30 August.

Coorey, Phillip. 2010b. 'The seven steps to power'. Sydney Morning Herald, 26 August.

Drape, Julian. 2010. 'Pairing Speaker not on, says Brandis'. Sydney Morning Herald, 22 September.

Eslake, Saul. 2010. 'Where is the vision?'. The Age, 25 August.

Gageler, Stephen. 2010a. In the Matter of the Governor-General: Opinion, SG No. 33 of 2010, 26 August.

Gageler, Stephen. 2010b. In the Matter of the Office of Speaker of the House of Representatives: Opinion, SG No. 37 of 2010, 22 September.

Gibson, Joel and Welch, Dylan. 2010. 'G-G seeks advice over possible conflict of interest in family link'. Sydney Morning Herald, 24 August.

Gillard, Julia. 2010. Letters to T. Windsor and R. Oakeshott, 7 September, Prime Minister, Parliament House, Canberra.

Gordon, Michael, Gibson, Joel and Welch, Dylan. 2010. 'GG in bind over Labor ties'. The Age, 24 August.

Greens. 2010. Greens-Labor Agreement. 2010, <www.greens.org.au>

Griffith, Gareth. 2010. Minority governments in Australia 1989-2009: accords, charters and agreements. Background Paper No. 1/10. Sydney: NSW Parliamentary Library Research Service.

Harris, I. C. [Pettifer, J. A.]. 2005 $\geq$ House of Representatives Practice. [Fifth edn]. Canberra: Department of the House of Representatives.

Horne, Nicholas. 2010. Hung Parliaments and Minority Governments. Canberra: Parliamentary Library, Parliament of Australia.

Justice Committee. 2010. Constitutional processes following a general electionfifth report, 16 March. London: House of Commons, UK Parliament.

Katter, Bob. 2010. 'Bob Katter's 20-point wish list'. Sydney Morning Herald, 3 September.

Mannheim, Markus. 2010. 'Hung parliament may help openness'. The Canberra Times, 23 August. 
Marks, Kathy. 2010. 'Now Australia gets a taste of hung parliaments'. The Independent [UK], 23 August.

Martin, A. W. 1993. Robert Menzies: A life. Volume 1: 1894-1943. Melbourne: Melbourne University Press.

Massola, James. 2010. 'Clear rules against independent speaker, says George Brandis'. The Australian, 22 September.

Murphy, Katharine and Arup, Tom. 2010. 'Independents use their power to get a good deal'. The Age, 26 August.

Shann, Ed. 2010. 'Transparency is the best policy'. Australian Financial Review, 26 August.

Smith, Rodney K. 2006. Against the Machines: Minor parties and independents in New South Wales. Sydney: Federation Press.

Smith, Tony. 2010. 'All MPs have independents envy'. Eureka Street 20(16) (27 August).

Stuchbury, Michael. 2010. 'The economic costs of a fractured parliament could break us'. The Australian, 28 August.

Tabakoff, Nick. 2010. 'Question of G-G's partiality -2010 nation in the balance'. The Daily Telegraph, 23 August.

Tedmanson, Sophie. 2010. 'Family politics are election decider dilemma for the Governor-General; Australia'. The Times [London], 24 August.

Tingle, Laura. 2010. 'Fears of chaos somewhat overblown'. Australian Financial Review, 26 November.

Twomey, Anne. 2010. The Governor-General's role in the formation of government in a hung parliament. Legal Studies Research Paper No. 10/85, August. Sydney: Sydney Law School.

White, Leslie. 2010. 'New seat of power for rural people'. Weekly Times, 25 August.

Wilkie, Andrew. 2010. Axis of Deceit: The extraordinary story of an Australian whistleblower. [Second edn]. Melbourne: Black Inc. Agenda.

Zumbo, Frank. 2010. 'Happy to be left hanging'. Mercury, 3 September. 